University of Michigan Law School

University of Michigan Law School Scholarship Repository

1916

\title{
Recovery of the Purchase Price before Title Has Passed
}

\author{
John B. Waite \\ University of Michigan Law School
}

Available at: https://repository.law.umich.edu/articles/664

Follow this and additional works at: https://repository.law.umich.edu/articles

Part of the Commercial Law Commons, Contracts Commons, Courts Commons, and the State and Local Government Law Commons

\section{Recommended Citation}

Waite, John B. (1912-1951). "Recovery of the Purchase Price before Title Has Passed." Mich. L. Rev. 14, no. 4 (1916): 320-5.

This Response or Comment is brought to you for free and open access by the Faculty Scholarship at University of Michigan Law School Scholarship Repository. It has been accepted for inclusion in Articles by an authorized administrator of University of Michigan Law School Scholarship Repository. For more information, please contact mlaw.repository@umich.edu. 


\section{Michigan LAW REVIEW}

Recovery of the Purchase Price Before, Title Has Passed.-In an action recently instituted by The General Electric Co. to recover on a contract to manufacture certain machinery for the defendant, which machinery the defendant had refused to accept, the trial court adopted the contract price as the measure of damages. The upper court approved this measure of damages, rejecting the argument that the measure should have been the difference between the market value and the contract price, and dismissed, as no longer appropriate to modern conditions, the decisions in Bement v. Smith, I5 Wend. (N. Y.) 493, and Shazwhan v. Van Nest. 25 Oh. St. 490. The court recognized, however, that these decisions had been sound when rendered. As they have frequently been referred to as anomalous rulings, it may be interesting to consider the effect upon them of this recent decision. Manhattan City, etc., Ry. Co. v. General Electric Co., 226 Fed. 173.

The rule is established, as a general proposition, that a vendor can not bring an action upon a contract of sale in indebitatus assumpsit for the purchase price until the title has passed. "The principle, concisely stated, is this-that a count for goods bargained and sold can only be maintained where the property in the goods has passed from the plaintiff to the defendant." Elliott v. Pybus, Io Bing. 510. If the goods are not in existence at 
the time of making the contract, or not then identified, no title can pass at that time. And it is settled, with but little exception, that title does not pass upon the mere identification, or bringing into existence of the goods. It is necessary that the vendor signify, in some way, his intention that the particular article so identified or manufactured be applied in execution of the particular contract. This intention may, however, be legally inferred from any facts tending to indicate it. Moody v. Brozen, $34 \mathrm{Me}$. I07; Mucklow v. MIangles, I Taunt. 318; Gabarron v. Kreeft, L. R. Io Exch. 274; Rider v. Kelley, 32 Vt. 268, $76 \mathrm{Am}$. Dec. I76; Johnson v. Hibbard, 29 Ore. I84, 54 Am. St. Rep. 787; Low v. Austin, 20 N. Y. I8I; Sawyer Medicine Co. v. Johnson, I78 Mass. 374.

But just as mutuality of intention is necessary to create the contract to sell, so mutuality of intention is necessary to effectuate the passing of title under it. Since the vendor is permitted, subsequent to the making of the contract, to select the goods which shall pass under it, it is but reasonable that the vendee should have an opportunity thereafter to assent to that selection. So it is held, both in England and in this country, that title does not pass until there has been both an indication of intent on the vendor's part to pass title to specific property, and an indication of acquiescence in such passing by the vendee. This acquiescence may, like the intent to pass title, be expressed or implied, and it may be demonstrated in any recognizable way. Elliott v. Pybus, to Bing. 512; Atkinson v. Bell, 8 B. \& C. 277 ; Campbell v. The Mersey Docks, I4 C. B., N. S. 4I2; Jenner v. Smith, L. R. 4 C. P. 270; Andrews v. Cheney, 62 N. H. 404; Smith v. Edzuards, I56 Mass. 22I; White v. Solomon, I64 Mass. 516; Rider v. Kelley, 32 Vt. 268; Greenleaf v. Gallagher, 93 Me. 549; Funke v. Allen, 54 Neb. 407; Unexcelled Fireworks Co. v. Polites, 130 Pa. 536 .

A few cases have gone so far as to say that title does pass to the buyer without the necessity of an assent thereto on his part. They have not, however, so held as an actual result, for in nearly all of them the facts are such as to show a real assent. In the case, for instance, of The Colorado Springs Live Stock Co. v. Godding, 20 Colo. 249, the court says, "The weight of authority is that the appropriation by the seller of an article, when completed in accordance with the terms of the contract, passes the title without the subsequent assent of the purchaser, and an action for the agreed price can be maintained." This is certainly not the weight of authority, and it is evident from the facts of the case that the court meant only that an acceptance of the goods as distinct from the title, was not necessary. An authorization from the vendee for the vendor to make the appropriation will usually be presumed in such circumstances, however, Johnison v. Hibbard, 29 Ore. I84. A somewhat similar dictum is found in Merchants National Bank v. Bangs, 102 Mass. 29I, but the Massachusetts courts clearly follow the general rule, and in the case itself there had been such delivery to a carrier and acceptance by it as is generally held to constitute a complete specification and assent. A clear conflict with the rule as expressed appears in Hayden v. Demets, 53 N. Y. 426 . Here a suit was allowed for the purchase price on 
the expressed theory that title had passed through the mere specification and tender by the vendor, without any assent on the vendee's part. No authority is cited and the case can be considered only as an exception.

There is, however, in this country a line of cases which allow a recovery by the vendor of the full amount of the purchase price, despite the fact that the vendee has never in any way assented to the passing of the title. The most frequently cited of these is Bement v. Smith, I5 Wend. (N. Y.) 493. These cases are frequently referred to, by both courts and text writers, as being in conflict with the principle expressed in Atkinson v. Bell, supra. (See Moody v. Brozen, 34 Me. I07.)

The principle on which such cases as Atkinson v. Bell have been decided is expressed, somewhat ineptly, in White v. Solomon, supra, as follows: "In an ordinary contract of sale the payment and the transfer of the goods are to be concurrent acts, and if the buyer refuses to accept the goods, even wrongfully, he cannot be sued for the price, because the event on which he undertook to pay the price has not happened; and although the fact that it has not happened is due to his own wrong, still he has not promised to pay the price in the present situation, but must be sued for his breach of contract in preventing the event on which the price would be due from coming to pass."

This principle is not denied in Bement v. Smith, nor does that case hold that a vendor has created a liquidated indebtedness in his favor without having passed the title for which he contracted. That case arose out of an understanding by the plaintiff to build for the defendant a sulky of a particular design, in return for which the defendant agreed to pay a certain sum of money. The defendant had refused to accept or to pay for the sulky when it was duly tendered by the plaintifi. In the trial court, "The judge $* * *$ charged the jury that the tender of the carriage was substantially a fulfillment of the contract on the part of the plaintiff, and that he was entitled to sustain his action for the price agreed upon between the parties." The issue before the upper court was as to the correctness of this charge. It was claimed that the measure of damages should have been not the value of the sulky, but only the expense of tender, delay, loss of sale, etc. The court held, however, that the full purchase price was due on the ground that the contract was a special one which had been fully performed by the plaintiff, and that he need not have declared at all as for goods bargained and sold.

The only conflict with Atkinson v. Bell is as to the character of the obligation created by the contract. In Atkinson v. Bell this type of contract was. held to have been a sale, obligating the vendor to transfer a title before he should acquire a right to payment by the vendee. In Bement v. Smith the contract was held to be one requiring only the performance of the work and labor agreed upon, and due tender of the result thereof.

This conflict in the interpretation of such contracts is well known. In England it is consistently held that every contract whose ultimate purpose is the transfer of title to a chattel is a contract of sale, even though work and labor are to be expended in creating such chattel. Lee v. Griffir, I Best \& S. 272. This is approximately the rule in some of our own states. 
But in New York, and a number of other states which follow the socalled "New York rule," a contract which provides for the manufacture of a chattel, even though title to it is eventually to be transferred, is held to be merely a contract for work and labor, and not to come within the Statute of Frauds as relating to sales. Cooke v. Millard, 65 N. Y. 352; Parsons v. Loucks, $48 \mathrm{~N}$. Y. 17. This distinction between the right to recover damages, only, in the event of breach of a contract of sale, and the right to recover the full agreed price when a contract for work and labor has been broken, is recognized in Gordon v. Norris, 49 N. H. 376 .

In these jurisdictions a contract of sale, nominally, of an article not yet in existence, being treated, legally, as a contract for work and labor, is obviously executed as soon as such work and labor is completed and tender made of the product. The so-called vendor having thus performed his obligation it is perfectly consistent to allow him an action for the contract price regardless of whether title to the chattel has been accepted by the vendee or not. This is criticized by Mr. WIILISTON (SALES, $\$ 563$ ), who says, "There, can be no doubt that the price is promised for the completed article, not for the work and materials which have gone into its manufacture." But while this assertion might create a sound argument for holding the contract to be one for the transfer of title, and not for work and labor merely, it has been rejected by the courts of these states in reference to the Statute of Frauds. It could not, therefore, be consistently accepted by them in cases where the issue merely concerns another aspect of the same matter, namely, the conditions precedent which the vendor has undertaken to perform.

In the case of Sharvhan v. Van Nest, 25 . Oh. St. 490, the Ohio court approved Bement v. Smith and followed it, saying, moreover, that they found it unnecessary to commit themselves as to whether or not a real "distinction resting upon principles of law can be drawn between ordinary sales of goods in existence and on the market, and goods made to order in a particular way, in pursuance of a contract between the vendor and vendee." In Missouri, where the holdings under the Statute of Frauds are much like those in England, there is a clear conflict with Atkinson v. Bell as to the right of the vendee to recover. Crown Vinegar and Spice Co. v. Wehrs, 59 Mo. App. 493 ; Walker v. Nixor, 65 Id. 326.

There is another type of cases, sometimes thought to be in conflict with Atkinson v. Bell, in which a vendor, under a true contract to sell, is permitted to recover the purchase price before title has passed. But the action in these cases is sustained on the ground that the vendee has contracted to pay as a condition precedent to the passing of title, upon the tender of the property or the doing of some other act, which the vendor has performed. Tufts v. Griffin, 107 N. C. 47 ; White v. Solomon, 164 Mass. 516; Burnley v. Tufts, 66 Miss. 48; Ackerman v. Rubens, 167 N. Y. 405. In this type of case it is obvious that the results are not in the least at variance with the propositions of the case referred to.

A statement of principle is found in many cases to the effect that, "The vendor of personal property in a suit against the vendee for not taking and paying for the property has the choice ordinarily of either one of three 
methods of indemnifying himself. (I) He may store or retain the property for the vendee, and sue him for the entire purchase price. $* * *$ "This statement appears to have been first made in the case of Dustan v. McAndrew, 44 N. Y. 72, but has been very often quoted with approval. If it be a correct expression of principle, it is in conflict with the general proposition that a vendor can not sue for the purchase price until title has passed. (The context of the expression often shows that by "taking and paying for" is meant not merely the possession of the goods but the title itself.)

But as a matter of fact it appears usually to have been made in decisions whose holdings have not gone to such an extreme. Thus, in Osgood v. Skinner, 2II I1l. 229, a suit to recover the full amount of the contract price was allowed, on the principle as stated. But, as a matter of fact, the property had been precisely specified at the time the contract was entered into, and the vendee had very clearly assented in advance to the passing of title. The court applied its expression to instances where no delivery of possession of the goods had occurred. In Moline Scale Co. v. Beed, 52 Iowa 307, the court intimates that an action would have been allowed for the purchase price, as such, although no title had passed, if a proper tender had been made. But Iowa follows the New York rule as to what are contracts for work and labor, and the particular case would have come under that designation. IowA. CODE (I897), § 4626 .

The expression quoted is also used in Kinkead v. Lynch, 132 Fed. 692. Here the action was really for damages for breach of contract and the full amount of the agreed price was allowed, not as such, but on the ground that there was no market value determinable for the good's manufactured. See also, Habeler v. Rogers, I3I Fed. 43.

In the Missouri case heretofore referred to (Crozen Vinegar and Spice Co. v. Wehrs) the statement of principle was actually followed. This was done on the ground that inasmuch as the vendor could not recover the cost of making a resale, to require him to make a resale would put him to unavoidable and irrecoverable expense; that a recovery of the full purchase price could do no one any harm, and that such recovery would be allowed. Only Missouri cases were cited as authority.

The only real conflict, therefore, among the cases, appears to be in the expressions used, and in the holdings of very occasional cases. They are all agreed that even when title has not passed an action may be brought to recover damages for breach of the contract. As said in Unexcelled Fireworks Co. v. Polites, I30 Pa. 536, "In the case of an executory contract for the sale of goods not specific, the rule undoubtedly is that the measure of damages for a refusal to receive the goods is the difference between the price agreed upon and the market value on the day appointed for delivery." The only real issue is as to the market value, in the special case, of the goods contracted for, by which the amount of damage is to be fixed. The principal case, probably the latest word on the subject, expresses the essence of the rule to which all the cases trend. The correctness of its finding that all the elements necessary to a decree of specific performance are present may well be doubted, but the propriety of allowing the full purchase price must 
be conceded. The court's statement is as follows: "To allow the seller to recover the full purchase price of an article, and compel the buyer to accept it whether he wants it or not, is to grant specific performance of a contract for the sale of personal property in favor of the seller, when no such relief could or would be granted in faror of the buyer. This is against the wellestablished doctrines of courts of equity. *** When the article is really a special manufacture to meet the peculiar needs of the buyer, and having no sale in the market, then every consideration which supports the specific performance of a contract for the sale of real property is present." "Whether the article is staple or not cannot be determined wholly by the form of the contract," and the court should receive evidence as to whether or not it has a probable market value.

J. B. W. 